\title{
Seed Germination of Five Poa Species at Negative Water Potentials
}

\author{
Tim L. Springer, Jason J. Goldman \\ Southern Plains Range Research Station, USDA-Agricultural Research Service, Woodward, OK, USA \\ Email: tim.springer@ars.usda.gov
}

Received 23 February 2016; accepted 20 March 2016; published 24 March 2016

Copyright (C) 2016 by authors and Scientific Research Publishing Inc.

This work is licensed under the Creative Commons Attribution International License (CC BY). http://creativecommons.org/licenses/by/4.0/

c) (i) Open Access

\begin{abstract}
Under field conditions water is often inadequate for satisfactory seed germination. An experiment was conducted to determine the effects of simulated dry conditions on germination and seedling growth of five bluegrass (Poa) species, including: Texas, $P$. arachnifera Torr.; annual, $P$. annua L.; mutton, P. fendleriana Vasey; Kentucky, P. pratensis L., and Sandberg, P. secunda J. Presl. bluegrasses. Fifty-seed samples of each species were germinated at water potentials of $-1.6,-0.8,-0.4$, -0.2, and 0 MPa for a 42-d period. Annual and Sandberg bluegrass tolerated moisture stress at germination better than the other species, requiring $14 \mathrm{~d}$ to reach $40 \%$ germination in water of -0.8 MPa potential. Kentucky bluegrass required 21 d to reach $40 \%$ germination under similar conditions. Mutton and Texas bluegrass were the least tolerant of low water potentials, requiring $42 \mathrm{~d}$ to reach $20 \%$ germination. Selection for increased seed germination at low water potentials should be possible in Poa species assuming the trait has moderate heritability.
\end{abstract}

\section{Keywords}

Negative Water Potential, Poa, Seed Germination

\section{Introduction}

The genus Poa consists of more than 300 species that occur in temperate regions throughout the world [1] [2]. Commonly known as "bluegrass" in North America and "meadow-grass" in Europe and Asia, many of the species are important pasture grasses which are palatable and nutritious to livestock [2]. Barkworth et al. [3] recognized 75 bluegrass species for North America. Of the 75 species listed, Kentucky bluegrass ( $P$. pratensis L.) is undoubtedly the most common and occurs in all 50 states of the USA [4]. Kentucky bluegrass has world importance where it is used for turf and for livestock forage [2]. Annual bluegrass (P. annua L.) is also of world importance as a weed and as a turfgrass and has been reviewed by Vargas and Turgeon [5]. Of regional importance, 
mutton bluegrass ( $P$. fendleriana Vasey) is adapted to cool temperatures and a variety of rangeland soils in the Rocky Mountains in the USA, making it excellent spring forage [4]. Texas bluegrass (P. arachnifera Torr.) is also adapted to a variety of soils in the central and southern Great Plains of the USA where it makes excellent winter forage for livestock [2]. Sandberg bluegrass ( $P$. secunda J. Presl) occurs throughout western North America providing spring and fall grazing to all classes of livestock and wildlife [6].

The germination characteristics of Kentucky bluegrass have been researched extensively. Hite [7] found that direct sunlight or diffuse light a few hours each day in alternating temperatures of $20^{\circ} \mathrm{C}-30^{\circ} \mathrm{C}$ gave a complete viability test for Kentucky bluegrass. The seed germination testing requirements for many Poa spp., including Kentucky bluegrass, are to germinate seeds in petri dishes or germination boxes on paper towel substrates moistened with distilled water incubated at $15^{\circ} \mathrm{C}-25^{\circ} \mathrm{C}$ for $16 \mathrm{~h}$ dark and $30^{\circ} \mathrm{C}$ for $8 \mathrm{~h}$ light for 21 to $35 \mathrm{~d}$; counting seedlings every 7 to $10 \mathrm{~d}$ [8]. The effects of salinity on germination of Kentucky bluegrass cultivars and other turfgrass species cultivars have been examined by Harivandi et al. [9] and Horst and Taylor [10]. Harivandi et al. [9] compared the germination of "Merion" Kentucky bluegrass; "Penfine” perennial ryegrass (Lolium perenne L.), "Seaside" creeping bentgrass (Agrostis palustris Huds.), "Dawson” slender creeping red fescue (Festuca rubra var. trichophylla Ducros ex Gaud.), "Fults" weeping alkaligrass [Puccinellia distans (L.) Parl.], and “common” Lemmon alkaligrass [Puccinellia lemmoni (Vasey) Scribn.] in soils with differing degrees of salinity and found that Kentucky bluegrass had the lowest germination percentage compared with the other five species. Horst and Taylor [10] reported differences among 44 cultivars of Kentucky bluegrass for their tolerance to germinate in saline (equal portions of $\mathrm{NaCl}$ and $\mathrm{CaCl}_{2}$ ) solutions. They concluded that enough variation existed among the 44 cultivars to breed and select for salt tolerance, but that apomictic reproduction may limit genetic improvement through recurrent selection. Larsen et al. [11] studied the interactions of water potential and temperature on the germination of Kentucky bluegrass, red fescue, and perennial ryegrass. They found that seed germination of all species decreased as water potential increased and that the interacting effects of temperature and water potential affected their ability to predict germination performance across all temperatures and water potential conditions.

Although periodic rainfall sometimes occurs during drought, it is virtually impossible for germinated seeds to become established and survive [12]. Moisture stress has been shown to decrease seed germination and seedling growth in several plant species [11] [13]-[16], and several experiments have simulated the effects of moisture stress on seed germination and growth of plants [13] [15]-[20]. These studies used a number of chemical compounds to simulate water deficits, such as carbowax 6000, D-mannitol, glucose, $\mathrm{NaCl}$, sucrose, polyethylene glycol (PEG), and polyvinylpyrrollidone. The most commonly used compounds are mannitol and polyethylene glycol because they are considered chemically inert and nontoxic to plant growth [15] [21].

Knowledge of seed germination can help plant breeders develop lines and/or cultivars with increased seed germination and seedling growth at low water potentials. For example, Springer [22] determined that it was possible to select for increased seed germination in sand bluestem (Andropogon hallii Hack.) using recurrent selection. He found after two selection cycles that 7-d seed germination was increased by $16.9 \%$ over that of the base population at a water potential of $-0.8 \mathrm{MPa}$ and under field conditions emergence was increased by $8.6 \%$ after two selection cycles [23]. Hodgson-Kratky [24] reported that three cycles of recurrent selection increased seed germination of Russian dandelion (Taraxacum kok-saghyz L. E. Rodin) breeding lines 34.5\% and 42.5\%, and reduced germination time 3 and $5 \mathrm{~d}$, respectively, for seeds incubated at low water potentials. Thus, the objective of this experiment was to determine the effects of moisture stress on the seed germination, rate of germination, and seedling growth of five Poa species.

\section{Materials and Methods}

\section{Plant Materials}

Seeds of mutton bluegrass, Kentucky bluegrass and Sandberg bluegrass used in this experiment were obtained from a commercial seed source. Seeds of annual bluegrass (PI 659870) were obtained from the National Genetic Resource Program, USDA-ARS [25], and seeds of Texas bluegrass were grown at the Southern Plains Range Research Station, USDA-ARS, Woodward, Oklahoma, USA (36 $25^{\prime} \mathrm{N}, 9^{\circ} 24^{\prime} \mathrm{W}$, elevation 586 m). Seeds of Texas bluegrass were harvested and processed according to the procedures of Goldman [26]. Species were selected based on modes of reproduction. In the laboratory seeds of all species were further processed using a South Dakota style seed blower (Seedburo, Chicago, IL, USA). Each seed lot was blown at an air value opening 
of $20 \mathrm{~mm}$ in $3 \mathrm{~g}$ increments to remove light and empty seed units as well as other inert materials. This blowing technique produced a heavy seed fraction that was approximately $98 \%$ pure seed for each species. The seeds were further examined using an illuminated magnifier to remove the remaining inert materials.

Forty, 50-seed samples of each species were counted from the processed seeds, weighed, and retained for two germination experiments. For each germination experiment, 20 of the 50 -seed samples of each species were randomly assigned to one of five water potential treatments. Water potential treatments of $-1.6,-0.8,-0.4,-0.2$ and $0 \mathrm{MPa}$ were prepared by mixing 58.3, 29.2, 14.6, 7.3, and $0 \mathrm{~g}$ of D-mannitol in $0.5 \mathrm{~kg}$ of deionized water, respectively [16]. Deionized water was used as a control, water potential $=0 \mathrm{MPa}$. D-mannitol was chosen because it acts as an inert osmotic medium [15] [21]. Fifty non-sterilized seeds of each species were placed in sterile, clear plastic boxes $(7.0 \times 7.0 \times 2.5 \mathrm{~cm})$ on two layers of absorbent paper towel substrates moistened with 7 $\mathrm{mL}$ of each water potential solution. Germination was conducted in a seed germinator (Seedburo Equipment Company, Chicago, IL, USA) set for $8 \mathrm{~h} \cdot \mathrm{d}^{-1}$ of fluorescent light at $30^{\circ} \mathrm{C}$ and $16 \mathrm{~h} \cdot \mathrm{d}^{-1}$ of darkness at $20^{\circ} \mathrm{C}$. These setting are the same as those used by Hite [7]. Cumulative "normal" germination counts were made at $7 \mathrm{~d}, 14 \mathrm{~d}$, $21 \mathrm{~d}, 28 \mathrm{~d}, 35 \mathrm{~d}$, and $42 \mathrm{~d}$ [22]. After $42 \mathrm{~d}$, the number of firm (non-germinated, apparently dormant) seed was recorded. In addition, a seedling classified as "normal" would possess both a root and a shoot each $2 \mathrm{~mm}$ or more in length. Seedlings with only a root and no shoot or a shoot and no root, but were otherwise normal in appearance, were retained in the germination box for an additional $7 \mathrm{~d}$ germination period. After $14 \mathrm{~d}$, if these seedlings had not grown the missing root or shoot, they were classified as "abnormal" [27]. Germination data were converted to percentages before analysis. The experimental design was a factorial arrangement of treatments (species and water potential) in a randomized block design with four replications. The experiment was repeated twice.

The rate (speed of germination) was determined using a modified procedure of Maguire [28]. Maguire [28] stated that, "The germination rate is calculated by dividing the number of normal seedlings per 100 seeds obtained at each counting in the standard germination test by the number of days the seeds have been in the germinator. The values obtained at each count are then summed at the end of the germination test to obtain the germination rate". Since only 50 seeds were used in each experimental unit, we modified the procedure by multiplying the number of seedling counted at each germination count by 2. In addition at each germination count, the root and shoot length of an average normal seedling was determined by using a millimeter ruler.

Data for percentage cumulative normal germination, percentage firm seed remaining and seedling root and shoot lengths were analyzed separately by species as a randomized complete block experiment using PROC GLIMMIX [29]. Water potential treatment was a fixed effect and blocks within experiments were a random effect. Mean separations were made using a least significant difference (LSD) test at $P \leq 0.05$. Linear, quadratic, and cubic effects were obtained for the water potential treatment for each bluegrass species using orthogonal polynomials [29].

\section{Results}

\subsection{Seed Germination}

Comparisons among bluegrass species were not performed because seeds were grown in different environments and the age of seeds at germination time were unknown. Therefore, data were analyzed by bluegrass species only making comparisons among water potential treatments. Water potential treatments for 7 - $42 \mathrm{~d}$ cumulative "normal" seed germination counts varied within species $(P<0.05)$. In general, as water potential decreased from -1.6 MPa to $0 \mathrm{MPa}$ the percentage germination increased. After a $42 \mathrm{~d}$ germination period, very little $(<$ $1 \%)$ or no germination occurred for bluegrass seeds germinated in water of $-1.6 \mathrm{MPa}$ potential. The effects of water potential treatment were linear $(P<0.01)$ and quadratic $(P<0.01)$ for annual bluegrass and germination was nearly complete in $28 \mathrm{~d}$ (Figure 1 ). In deionized water $(0 \mathrm{MPa})$ more than $60 \%$ of the seed of annual bluegrass germinated in $7 \mathrm{~d}$. Annual bluegrass had the lowest seed weights, but had high rates of germination (Table 1). Similarly, the effects of water potential treatment were linear $(P<0.01)$ and quadratic $(P<0.01)$ for Sandberg bluegrass, and germination was complete in $21 \mathrm{~d}$ at all water potential treatments (Figure 2). Approximately $60 \%$ of the germinable seeds of Sandberg bluestem germinated within $7 \mathrm{~d}$ in deionized water (0 Mpa, Figure 2). Sandberg bluegrass had the second highest rates of germination at all water potential treatments and the second highest seed weight (Table 1). The effects of water potential treatment were linear $(P<0.01)$ and quadratic $(P<0.01)$ for Kentucky bluegrass, and germination was complete in $21 \mathrm{~d}$ (Figure 3 ). Less than $20 \%$ 
Table 1. Mean \pm SE for 50-seed weight for five Poa species and germination rates of the species at four water potentials.

\begin{tabular}{cccccc}
\hline & & \multicolumn{4}{c}{ Germination rate at water potential treatment (MPa) } \\
\hline Poa species & 50 -seed weight $(\mathrm{mg})$ & -0.8 & -0.4 & -0.2 & 0 \\
\hline annua & $15.0 \pm 0.22$ & $4.2 \pm 0.28 \mathrm{a}^{\dagger}$ & $7.9 \pm 0.28 \mathrm{~b}$ & $9.1 \pm 0.28 \mathrm{c}$ & $10.8 \pm 0.28 \mathrm{~d}$ \\
arachnifera & $16.8 \pm 0.22$ & $0.5 \pm 1.02 \mathrm{a}$ & $1.9 \pm 1.02 \mathrm{~b}$ & $2.3 \pm 1.02 \mathrm{~b}$ & $3.6 \pm 1.02 \mathrm{c}$ \\
fendleriana & $32.5 \pm 0.22$ & $0.8 \pm 0.43 \mathrm{a}$ & $2.8 \pm 0.43 \mathrm{~b}$ & $3.1 \pm 0.43 \mathrm{~b}$ & $4.2 \pm 0.43 \mathrm{c}$ \\
pratensis & $18.3 \pm 0.22$ & $2.9 \pm 0.57 \mathrm{a}$ & $4.7 \pm 0.57 \mathrm{~b}$ & $5.1 \pm 0.57 \mathrm{~b}$ & $6.7 \pm 0.57 \mathrm{c}$ \\
secunda & $29.1 \pm 0.22$ & $3.9 \pm 0.89 \mathrm{a}$ & $6.6 \pm 0.89 \mathrm{~b}$ & $7.1 \pm 0.89 \mathrm{~b}$ & $9.5 \pm 0.89 \mathrm{c}$ \\
\hline
\end{tabular}

${ }^{\dagger}$ Means of germination rates at different water potential treatment followed by the same letter within species (row) are not significantly different at $P>$ 0.05 (LSD test).

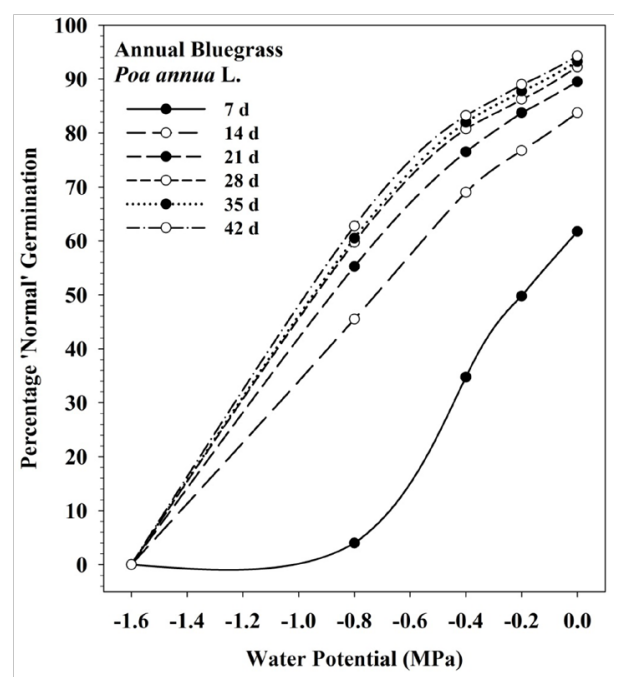

Figure 1. Percentage 7-d through 42-d seed germination of annual bluegrass, Poa annua L., germinated at five water potentials. SE of means was $1.9 \%$ for $7 \mathrm{~d}$ germination, $4.0 \%$ for $14 \mathrm{~d}$ germination, $3.3 \%$ for $21 \mathrm{~d}$ germination, $2.7 \%$ for $28 \mathrm{~d}$ germination, $2.7 \%$ for $35 \mathrm{~d}$ germination, and $2.5 \%$ for $42 \mathrm{~d}$ germination.

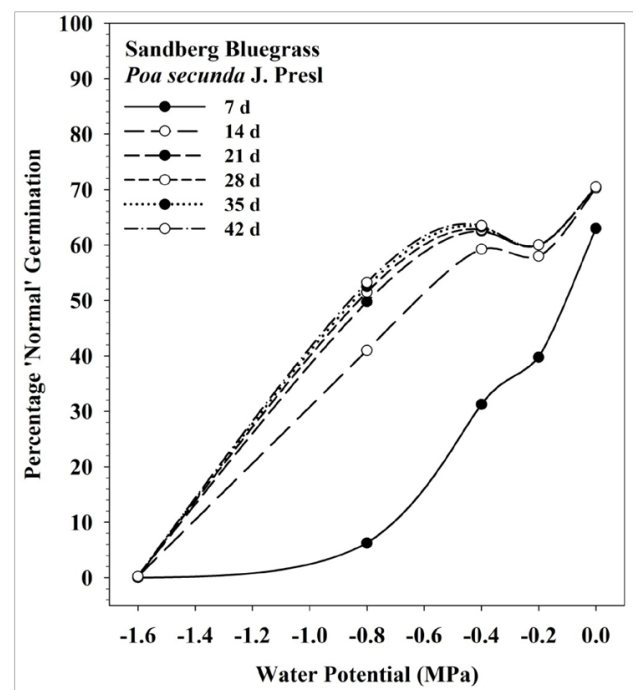

Figure 2. Percentage 7-d through 42-d seed germination of Sandberg bluegrass, Poa secunda J. Presl, germinated at five water potentials. SE of means were $4.3 \%$ for $7 \mathrm{~d}$ germination, $6.3 \%$ for $14 \mathrm{~d}$ germination, $6.6 \%$ for $21 \mathrm{~d}$ germination, $6.4 \%$ for $28 \mathrm{~d}$ germination, $6.1 \%$ for $35 \mathrm{~d}$ germination, and $5.9 \%$ for $42 \mathrm{~d}$ germination. 


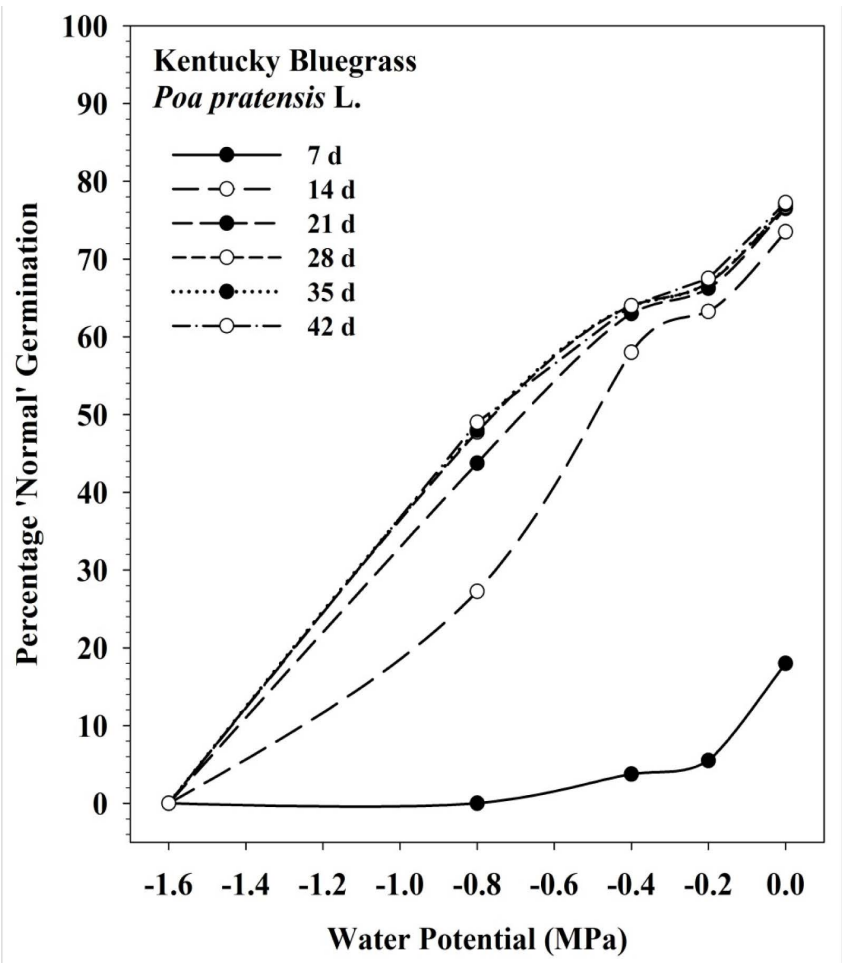

Figure 3. Percentage 7-d through 42-d seed germination of Kentucky bluegrass, Poa pratensis L., germinated at five water potentials. SE of means were $1.8 \%$ for $7 \mathrm{~d}$ germination, $5.9 \%$ for $14 \mathrm{~d}$ germination, $8.5 \%$ for $21 \mathrm{~d}$ germination, $9.2 \%$ for $28 \mathrm{~d}$ germination, $9.1 \%$ for $35 \mathrm{~d}$ germination, and $9.1 \%$ for $42 \mathrm{~d}$ germination.

of the seeds of Kentucky bluegrass germinated in $7 \mathrm{~d}$ at a water potential of $0 \mathrm{MPa}$. Kentucky bluegrass had an intermediate rate of germination and seed weight (Table 1). For mutton bluegrass, the effects of water potential treatment were linear $(P<0.01)$ and cubic $(P<0.01$, Figure 4$)$. In deionized water, less than $50 \%$ of the mutton bluegrass seeds germinated in $14 \mathrm{~d}$. Mutton bluegrass had slow but steady germination, but when water stressed, germination was below 50\%. Mutton bluegrass had the heaviest seed and the second lowest rate of germination at all water potential treatments (Table 1$)$. The effect of water potential treatment was linear $(P<0.01)$ for Texas bluegrass. Texas bluegrass had the slowest rate of germination at all water potential treatments with slightly over $50 \%$ of seeds germinating in $21 \mathrm{~d}$ (Table 1, Figure 5). Like mutton bluegrass, Texas bluegrass had slow but steady increases in germination for water potentials between $-0.8 \mathrm{MPa}$ through $0 \mathrm{MPa}$. Texas bluegrass had the second lowest seed weight (Table 1).

\subsection{Non-Germinated Seeds}

As water potential decreased from -1.6 MPa to $0 \mathrm{MPa}$ the percentage of firm (non-germinated) seed after $42 \mathrm{~d}$ in the germinator decreased (Figure 6), and the modeling of water potential data as to linear, quadratic, and/or cubic was the same as that for cumulative "normal" germination data as outlined above. Except for mutton bluegrass, the percentage of firm seeds remaining after $42 \mathrm{~d}$ in the germinator ranged from $78 \%-90 \%$. The percentage of firm seeds was high for mutton bluegrass and Texas bluegrass for water potential -0.8 MPa through 0 MPa indicating that germination was not complete for these species even after $42 \mathrm{~d}$ (Figure 6).

\subsection{Seedling Roots and Shoots}

The root lengths of 7-d old seedlings increased as water potential decreased from -1.6 MPa to 0 MPa (Figure 7). The five species exhibited linear effects $(P<0.01)$. Three species, Kentucky bluegrass, Sandberg bluegrass and Texas bluegrass, also displayed quadratic effects $(P<0.01)$. Sandberg bluegrass had the longest seedling root lengths at all water potential treatments (Figure 7). 


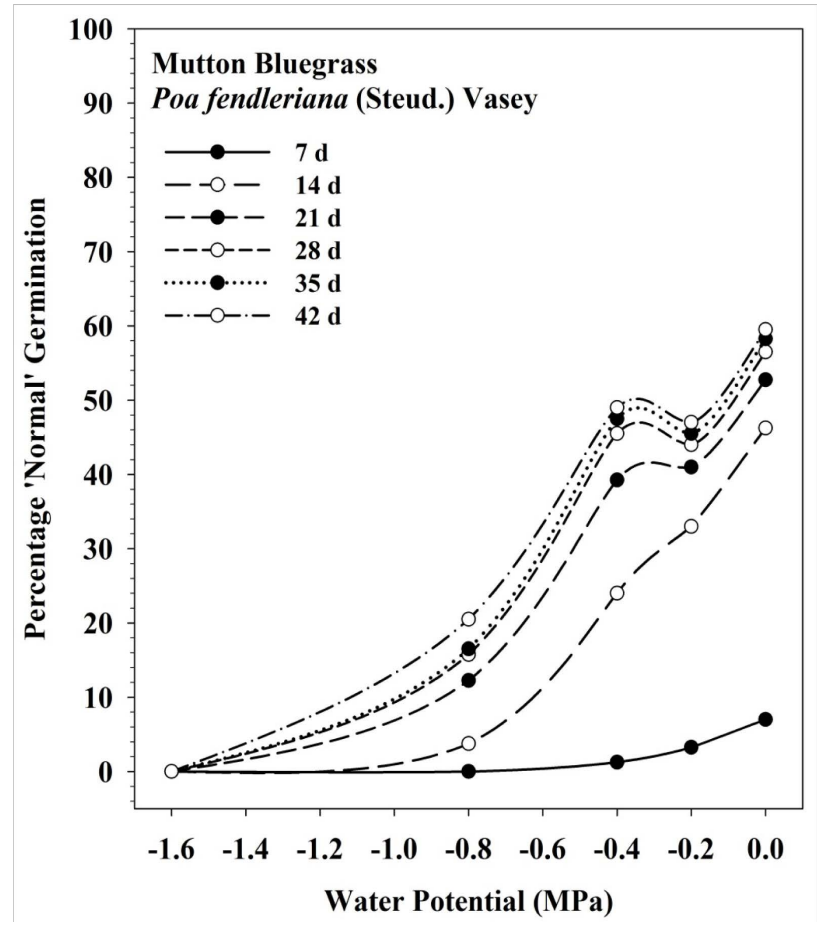

Figure 4. Percentage 7-d through 42-d seed germination of mutton bluegrass, Poa fendleriana (Steud.) Vasey, germinated at five water potentials. SE of means were $0.9 \%$ for $7 \mathrm{~d}$ germination, $3.7 \%$ for $14 \mathrm{~d}$ germination, $6.0 \%$ for $21 \mathrm{~d}$ germination, $5.5 \%$ for $28 \mathrm{~d}$ germination, $5.3 \%$ for $35 \mathrm{~d}$ germination and $5.4 \%$ for $42 \mathrm{~d}$ germination.

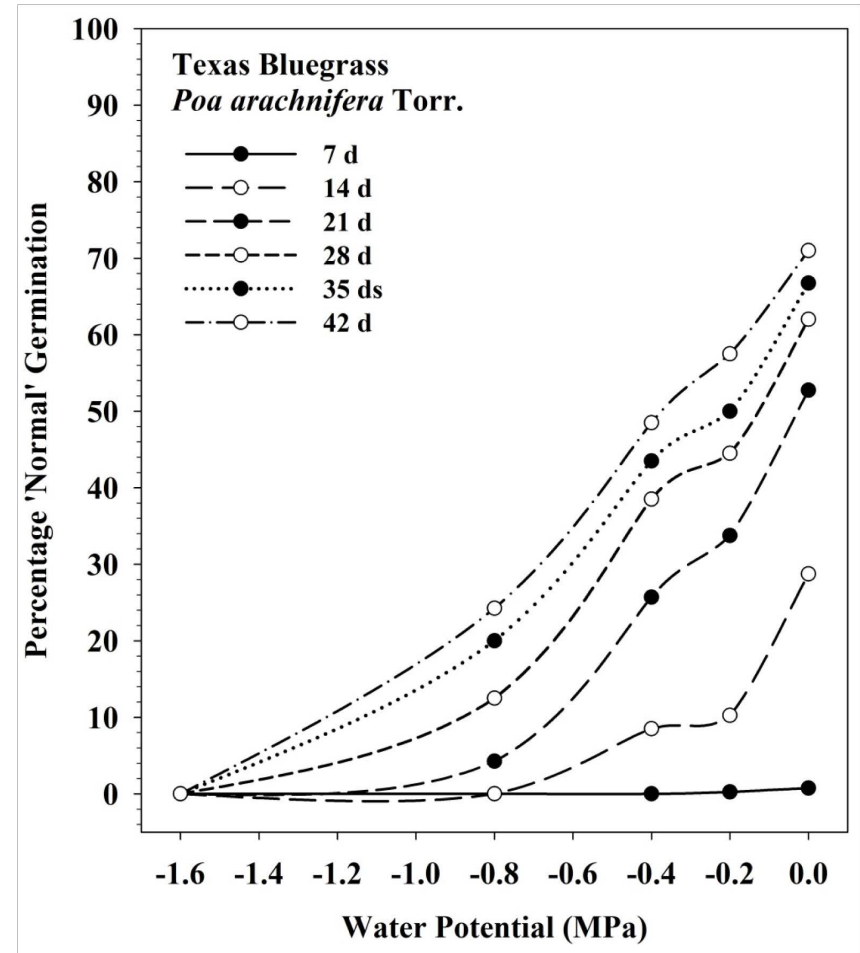

Figure 5. Percentage 7-d through 42-d seed germination of Texas bluegrass, Poa arachnifera Torr., germinated at five water potentials. SE of means were $0.3 \%$ for $7 \mathrm{~d}$ germination, $6.6 \%$ for $14 \mathrm{~d}$ germination, $13.3 \%$ for $21 \mathrm{~d}$ germination, $15.0 \%$ for 28 d germination, $15.8 \%$ for 35 d germination, and $14.7 \%$ for $42 \mathrm{~d}$ germination. 


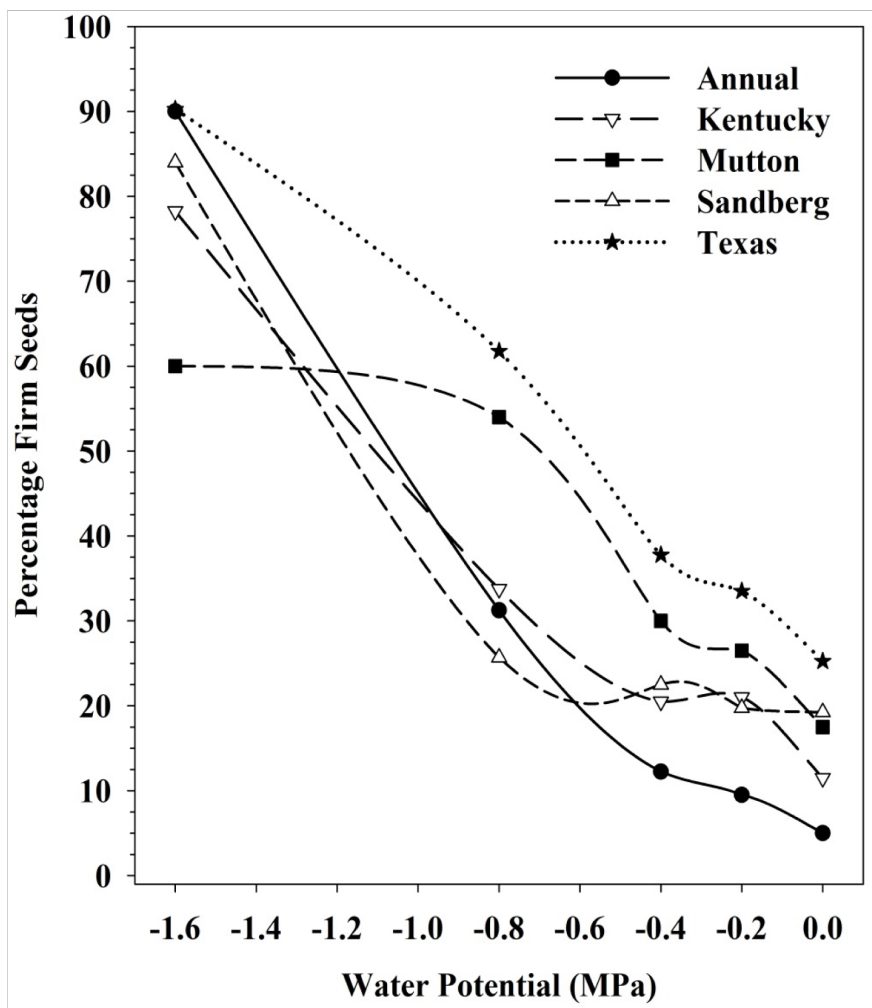

Figure 6. Percentage non-germinated (firm) seed remaining after a42 d germination period for the five bluegrass species germinated at five water potentials. Annual, Poa annua L.; Kentucky, P. pratensis L.; Mutton, P. fendleriana (Steud.) Vasey; Sandberg, P. secunda J. Presl; and Texas, P. arachnifera Torr. SE of means is $4.8 \%$.

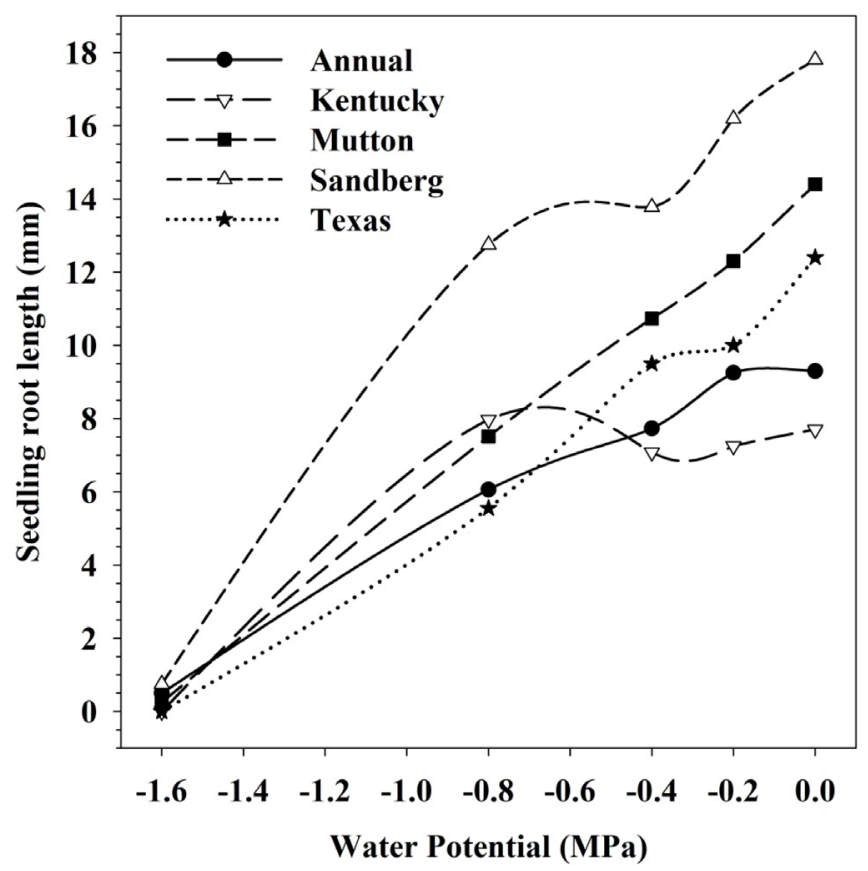

Figure 7. Seedling root length for the five bluegrass species germinated for $7 \mathrm{~d}$ at five water potentials. Annual, Poa annua L.; Kentucky, P. pratensis L.; Mutton, P. fendleriana (Steud.) Vasey; Sandberg, P. secunda J. Presl; and Texas, P. arachnifera Torr. SE of means is $1.3 \mathrm{~mm}$. 
The shoot lengths of 7-d old seedlings also increased as water potential decreased from $-1.6 \mathrm{MPa}$ to $0 \mathrm{MPa}$ (Figure 8). All species exhibited linear effects $(P<0.01)$ and two species, Kentucky bluegrass and Texas bluegrass, also displayed quadratic effects $(P<0.01)$. Sandberg bluegrass also had the longest seedling shoot lengths at all water potential treatments, while the seedling shoot length for Kentucky bluegrass ranged from 6-to-8 mm for water potential treatments $-0.8 \mathrm{MPa}$ to $0 \mathrm{MPa}$ (Figure 8).

\section{Discussion}

Annual bluegrass and Sandberg bluegrass appeared to tolerate moisture stress better than the other bluegrass species tested; still, it required $14 \mathrm{~d}$ for these species to reach $40 \%$ germination in water of $-0.8 \mathrm{MPa}$ potential (Figure 1 and Figure 2). Likewise, it required $21 \mathrm{~d}$ for Kentucky bluegrass to do the same (Figure 3). Mutton bluegrass and Texas bluegrass were the least tolerant of low water potentials, requiring $42 \mathrm{~d}$ to reach approximately 20\% germination (Figure 4 and Figure 5). Rapid germination is an important factor influencing stand establishment of grasses [30]. In this experiment annual bluegrass and Sandberg bluegrass had the highest rates of germination at water potentials between $-0.8 \mathrm{MPa}$ through $0 \mathrm{MPa}$ (Table 1 ).

Very little germination occurred in water of $-1.6 \mathrm{MPa}$ potential. Except for mutton bluegrass, the percentage of non-germinated firm seeds remaining after a $42 \mathrm{~d}$ germination period exceeded $75 \%$ (Figure 6). As expected, seedling root and shoot lengths declined as water potential increased. Root and shoot lengths of seedlings that germinated at $-0.8 \mathrm{MPa}$ in $7 \mathrm{~d}$ were $65 \%$ and $58 \%$ of the control (0 MPa). Parmar and Moore [15] reported root and shoot lengths of corn (Zea mays L.) seedlings that germinated at $-1.01 \mathrm{MPa}$ in $5 \mathrm{~d}$ were $55 \%$ and $32 \%$ of the control (0 MPa). Springer [16] reported root and shoot lengths of seedlings of chaffy-seeded grasses that germinated at $-0.8 \mathrm{MPa}$ in $7 \mathrm{~d}$ were $62 \%$ and $45 \%$ of the control ( $0 \mathrm{MPa}$ ).

It is possible to improve germination by using phenotypic recurrent selection in sand bluestem [22] [31]. Selecting seeds that germinated at a water potential of $-0.8 \mathrm{MPa}$ resulted in improved populations of sand bluestem that averaged $9.1 \% \pm 1.8 \%$ increased germination each selection cycle. In addition to selecting for increased seed germination, Springer [22] simultaneously selected for increased spikelet weight, seedling root length, and increased field establishment [31]. Recurrent selection has been used successfully for population improvement

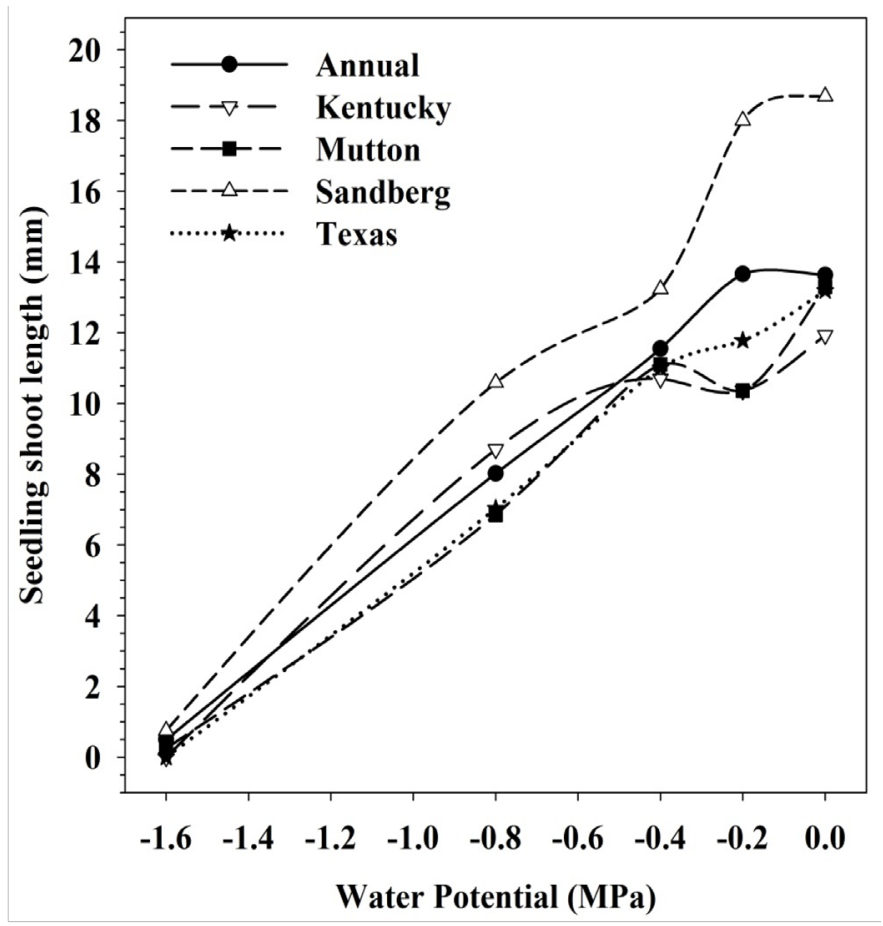

Figure 8. Seedling shoot length for the five bluegrass species germinated for $7 \mathrm{~d}$ at five water potentials. Annual, Poa annua L.; Kentucky, $P$. pratensis L.; Mutton, $P$. fendleriana (Steud.) Vasey; Sandberg, $P$. secunda J. Presl; and Texas, $P$. arachnifera Torr. SE of means is $1.1 \mathrm{~mm}$. 
and cultivar development in several cross-pollinated forage grasses [32]. The use of phenotypic recurrent selection in isolated polycross nurseries allows for the removal of less desirable plant genotypes, thereby increasing the frequency of superior genotypes in the next generation [33].

There are several breeding systems among bluegrass species each presenting challenges for genetic improvement [2] [34]. For example, annual bluegrass is gynomonoecious having both pistillate and hermaphroditic flowers on the same plant [2]. Although annual bluegrass possesses an outbreeding system of reproduction, it is self-compatible which may lead to a high degree of homozygosity. Self-compatibility is a positive pollination mechanism which insures optimal seed production and, it is a considerable advantage for annual plant species [35]. Breeding for improved germination would require testing and selection among many genotypes.

Except for the slowed germination response of Kentucky bluegrass at 7 d, Kentucky bluegrass and Sandberg bluegrass had similar germination patterns. Both of these species reproduce by aposporus apomixis, where an unreduced embryo sac is formed from a somatic cell of the nucellus or chalaza giving rise to an embryo that is formed without fertilization [2] [35] [36]. Obligate apomixis is considered a genetic dead end without the occurrence of sexual reproduction [35]. Kentucky bluegrass produces both apomictic and sexual reproducing flowers. Horst and Taylor [10] found that variation existed among the 44 cultivars of Kentucky bluegrass they tested to breed and select for salt tolerance, but that apomictic reproduction slowed the genetic improvement through recurrent selection. In highly apomictic bluegrass species, direct selection of genotypes for germination at low water potentials should produce superior genotypes for that trait. Several forage grass species that reproduce through apospory have been selected for superior traits and released as cultivars [37]-[39].

Mutton bluegrass is incompletely dioecious [40] with plants usually pistillate or occasionally hermaphroditic [41] and depending on the subspecies reproduces either by apospory apomixis and/or sexual reproduction [3] [41] [42]. Texas bluegrass is completely dioecious [3] and reproduces by sexual reproduction. For sexual reproducing forms of mutton bluegrass and for Texas bluegrass recurrent selection should be possible assuming the trait has moderate heritability. For the genotype of mutton bluegrass tested in this experiment, approximately 5\% of the seed germinated in water of - $0.8 \mathrm{MPa}$ potential in $14 \mathrm{~d}$. Similarly, for the line of Texas bluegrass tested, approximately $5 \%$ of the seed germinated in water of $-0.6 \mathrm{MPa}$ water potential in $14 \mathrm{~d}$. By using the techniques of Springer [22], it should be possible to improve seed germination at a low water potential and possibly improve seedling vigor by increasing the rate of germination and size of the caryopsis and seedling. Thus, improving stand establishment.

\section{Conclusion}

Moisture stress affected the percentage of seed germination, rate of seed germination, and seedling growth of the Poa species tested. For these five bluegrass species very little germination occurred in water of -1.6 MPa potential and as water potential decreased from -1.6 to $0 \mathrm{MPa}$ there was a curvilinear increase in seed germination overall. Annual bluegrass and Sandberg bluegrass had the highest rates of germination compared with the other bluegrass species. Seedling root and shoot lengths increased as water stress decreased. After determining a water potential where approximately $5 \%$ of the seeds germinate in a set period of time (e.g., $7 \mathrm{~d}$ or $10 \mathrm{~d}$ ), selection for increased seed germination at a low water potential should be possible in Poa species.

\section{Acknowledgements}

Funding for this research was provided by USDA-ARS. All programs and services of the USDA are offered on a nondiscriminatory basis, without regard to race, color, national origin, religion, sex, age, marital status or handicap. Mention of a trademark or a proprietary product does not constitute a guarantee or warranty of the product by USDA and does not imply approval to the exclusion of other suitable products.

\section{References}

[1] Balasko, J.A., Evers, G.W. and Duell, R.W. (1995) Bluegrasses, Ryegrasses, and Bentgrasses. In: Barnes, R.F., Miller, D.A. and Nelson, J.C., Eds., Forages, Volume 1, Iowa State University Press, Ames, 357-371.

[2] Wedin, W.F. and Huff, D.R. (1996) Bluegrasses. In: Moser, L.E., Buxton, D.R., and Casler. M.D., Eds., Cool-Season Forage Grasses, American Society of Agronomy Inc., Crop Science Society of America Inc., Soil Science Society of America Inc., Madison, 665-690.

[3] Barkworth, M.E., Anderson, L.K., Carpels, K.M., Long, S. and Piep, M.B. (2007) Manual of Grasses of North America. 
Utah State University Press, Logan.

[4] Fergus, E.N. and Buckner, R.C. (1973) The Bluegrasses and Redtop. In: Heath, M.E., Metcalfe, D.S. and Barnes, R.F., Eds., Forages the Science of Grassland Agriculture, Iowa State University Press, Ames, 243-253.

[5] Vargas Jr., J.M. and Turgeon, A.J. (2004) Poa annua: Physiology, Culture, and Control of Annual Bluegrass. John Wiley \& Sons Inc., Hoboken.

[6] United States Department of Agriculture (2009) Natural Resources Conservation Service. Plants Guide: Sandberg Bluegrass, Poa secunda J. Presl. http://plants.usda.gov/plantguide/pdf/pg_pose.pdf

[7] Hite, B.C. (1919) Forcing the Germination of Bluegrass. Proceedings of the Association of Official Seed Analysts of North America, 11, 53-58.

[8] AOSA (2014) Rules for Testing Seeds. Association of Official Seed Analysts (AOSA), Washington DC.

[9] Harivandi, M.A., Butler, J.D. and Soltanpour, P.M. (1982) Salt Influence on Germination and Seedling Survival of Six Cool-Season Turfgrass Species. Communications in Soil Science and Plant Analysis Journal, 13, 519-529. http://dx.doi.org/10.1080/00103628209367291

[10] Horst, G.L. and Taylor, R.M. (1983) Germination and Initial Growth of Kentucky Bluegrass in Soluble Salts. Agronomy Journal, 75, 679-681. http://dx.doi.org/10.2134/agronj1983.00021962007500040024x

[11] Larsen, S.U., Bailly, C., Côme, D. and Corbineau, F. (2004) Use of the Hydrothermal Time Model to Analyse Interacting Effects of Water and Temperature on Germination of Three Grass Species. Seed Science Research, 14, 35-50. http://dx.doi.org/10.1079/ssr2003153

[12] Blake, A.K. (1935) Viability and Germination of Seeds and Early Life History of Prairie Plants. Ecological Monographs, 5, 405-460. http://dx.doi.org/10.2307/1943035

[13] Helmerick, R.H. and Pfeifer, R.P. (1954) Differential Varietal Response of Winter Wheat Germination and Early Growth to Controlled Limited Moisture Conditions. Agronomy Journal, 46, 560-562. http://dx.doi.org/10.2134/agronj1954.00021962004600120007x

[14] Wiggins, S.C. and Gardner, F.P. (1959) Effectiveness of Various Solutions for Simulating Drought Conditions as Measured by Germination and Seedling Growth. Agronomy Journal, 51, 315-318. http://dx.doi.org/10.2134/agronj1959.00021962005100060002x

[15] Parmar, M.T. and Moore, R.P. (1968) Carbowax 6000, Mannitol, and Sodium Chloride for Simulating Drought Conditions in Germination Studies of Corn (Zea mays L.) of Strong and Weak Vvigor. Agronomy Journal, 60, $192-195$. http://dx.doi.org/10.2134/agronj1968.00021962006000020015x

[16] Springer, T.L. (2005) Germination and Early Seedling Growth of Chaffy-seeded Grasses at Negative Water Potentials. Crop Science, 45, 2075-2080. http://dx.doi.org/10.2135/cropsci2005.0061

[17] McGinnies, W.J. (1960) Effects of Moisture Stress and Temperature on Germination of Six Range Grasses. Agronomy Journal, 52, 159-162. http://dx.doi.org/10.2134/agronj1960.00021962005200030012x

[18] Knipe, O.D. (1973) Western Wheatgrass Germination as Related to Temperature, Light, and Moisture Stress. Journal of Range Management, 26, 68-69. http://dx.doi.org/10.2307/3896892

[19] Sharma, M.L. (1973) Simulation of Drought and its Effect on Germination of Five Pasture Grasses. Agronomy Journal, 65, 982-987. http://dx.doi.org/10.2134/agronj1973.00021962006500060041x

[20] Sharma, M.L. (1976) Interaction of Water Potential and Temperature Effects on Germination of Three Semi-Arid Plant Species. Agronomy Journal, 68, 390-394. http://dx.doi.org/10.2134/agronj1976.00021962006800020048x

[21] Bell, D.T. (1974) The Influence of Osmotic Pressure in Tests for Allelopathy. Transactions of the Illinois State Academy of Science, 67, 312-317.

[22] Springer, T.L. (2011) Recurrent Selection for Increased Seed Germination in Sand Bluestem (Andropogon hallii). Plant Breeding, 131, 198-202. http://dx.doi.org/10.1111/j.1439-0523.2011.01899.x

[23] Springer, T.L., Wynia, R.L. and Rea, G.L. (2012) Field Emergence and Plant Density of Sand Bluestem Lines Selected for Increased Seed Germination. Crop Science, 52, 2826-2829. http://dx.doi.org/10.2135/cropsci2012.02.0108

[24] Hodgson-Kratky, K. (2015) Breeding for Improved Germination under Water Stress, and Genetic Analyses of Flowering Habit and Male Sterility in Russian Dandelion (Taraxacum kok-saghyz). M.S. Thesis, The University of Guelph, Guelph.

[25] United States Department of Agriculture (2015) Agricultural Research Service, National Genetic Resources Program. Germplasm Resources Information Network (GRIN). National Germplasm Resources Laboratory, Beltsville. http://www.ars-grin.gov.4/cgi-bin/npgs/acc/display.pl?1706786

[26] Goldman, J.J. (2012) No-Till Drill Planting of Texas Bluegrass on the Southern Plains. Native Plants Journal, 13, 51-55. http://dx.doi.org/10.3368/npj.13.1.51 
[27] Colbry, V.L., Swofford, T.F. and Moore, R.P. (1961) Tests for Germination in the Laboratory. In: Stefferus, A., Ed., Seeds: The Yearbook of Agriculture, United States Government Printing Office, Washington DC, 433-443.

[28] Maguire, J.D. (1962) Speed of Germination-aid in Selection and Evaluation for Seedling Emergence and Vigor. Crop Science, 2, 176-177. http://dx.doi.org/10.2135/cropsci1962.0011183X000200020033x

[29] SAS Institute, Inc. (2010) SAS/STAT® User’s Guide. Version 9.22, SAS Institute, Cary. http://support.sas.com/documentation/cdl/en/statug/63347/HTML/default/viewer.htm\#statug_intro_sect010.htm

[30] Shaidaee, G., Dahl, B.E. and Hansen, R.M. (1969) Germination and Emergence of Different Age Seeds of Six Grasses. Journal of Range Management, 22, 240-243. http://dx.doi.org/10.2307/3895925

[31] Springer, T.L., Wynia, R.L. and Rea, G.L. (2014) Registration of “Centennial” Sand Bluestem. Journal of Plant Registration, 8, 248-252. http://dx.doi.org/10.3198/jpr2014.05.0032crc

[32] Burton, G.W. (1982) Improved Recurrent Restricted Phenotypic Selection Increases Bahia Forage Yields. Crop Science, 22, 1058-1061. http://dx.doi.org/10.2135/cropsci1982.0011183X002200050040x

[33] Sleper, D.A. (1987) Forage Grasses. In: Fehr, W.R., Ed., Principles of Cultivar Development, Vol. 2, Macmillan Publishing Company, New York, 161-208.

[34] Anton, A.M. and Conner, H.E. (1995) Floral Biology and Reproduction in Poa (Poeae: Gramineae). Australian Journal of Botany, 43, 577-599. http://dx.doi.org/10.1071/BT9950577

[35] Radford, A.E., Dickison, W.C., Massey, J.R. and Bell, C.R. (1974) Vascular Plant Systematics. Harper and Row Publishers, New York.

[36] Kellogg, E.A. (1987) Apomixis in the Poa secunda Complex. American Journal of Botany, 74, 1431-1437. http://dx.doi.org/10.2307/2444319

[37] Dewald, C.L., Sims, P.L., Berg, W.A. and White, L.M. (1988) Registration of “WW-Iron Master” Old World Bluestem. Crop Science, 28, 198-190. http://dx.doi.org/10.2135/cropsci1988.0011183X002800010050x

[38] Grabowski, J.M., Douglas, J.L., Lang, D.L. and Edwards, S.D. (2005) Registration of “Highlander” Eastern Gamagrass. Crop Science, 45, 412-413. http://dx.doi.org/10.2135/cropsci2005.0412

[39] Hussey, M.A. and Burson, B.L. (2005) Registration of “Frio” Buffelgrass. Crop Science, 45, 411-412. http://dx.doi.org/10.2135/cropsci2005.0411

[40] Hitchcock, A.S. (1951) Manual of the Grasses of the United States. 2nd Edition, Revised by Chase, A., USDA, Miscellaneous Publication, No. 200, US Government Printing Office, Washington DC. http://dx.doi.org/10.5962/bhl.title.65332

[41] Soreng, R.J. (1991) Systematics of the Epiles Group of Poa (Poaceae). Systematic Botany, 16, 507-583. http://dx.doi.org/10.2307/2419340

[42] Soreng, R.J. and Van Devender, T.R. (1989) Late Quaternary Fossils of Poa fendleriana (Muttongrass): Holocene Expansion of Apomicts. Southwest Naturalist, 34, 35-45. http://dx.doi.org/10.2307/3671807 